\title{
Michael Haneke Filmlerinde Modern Ailenin Tekinsiz Halleri
}

\section{Sabire SOYTOK*}

\section{Özet}

Haneke şüphesiz günümüz sinemasının en tartışmalı yönetmenlerinden biridir. Filmlerinde, burjuva toplumunun sermayeye dayalı yapısında, modern bireylerin çalışmaya odaklı hayatlarının kompartımanlaşması sonucunda, içine kapanan, yabancılaşan ve aşırı bireyselleşen yaşamlarının nasıl etkilendiği üzerine sorular sorar. Yabancılaşma ve içine kapanma bireyleri yalnızlaştırırken, filmlerinde yabancılaşmış bireyin öteki olarak varlık gösteren ve tehdit oluşturan davranışlarını anlamaya çalışır. Modern bireyi ailenin içine yerleştirerek, sınırlarını belirler. Bireyin davranışlarını anlamak için, modern toplumların ve sinemanın en korunaklı alanı kabul edilen orta sınıf burjuva ailelerinin hayatlarını, davranış biçimlerini inceler ve tekinsizin oldukça korunaklı aile ortamında nasıl oluştuğu üzerinde durur. Haneke filmlerinde ailelerin çoğu kez, şiddetin kurbanı ya da failleri olması, aile ortamı içinde tekinsizlik hissini kuvvetlendirmekte, korku ve endişe yaratmakta ve aile olgusunu yeniden tartışmaya açmaktadır. Günlük yaşamında kendini güvensiz hisseden seyirci, doğal olarak Haneke filmlerinde -ki bu filmler ne korku ne de gerilim olmamasına karşın- gördükleri karşısında rahatsız olacaktır. Klasik anlatı kurallarına göre seyirci, özdeşleşme kuracağı karakterin ne zaman ve hangi koşullarda, neye dönüşeceğini bilmek ister, tersi durum tedirginlik yaratır. Haneke'nin filmlerinde karakterlerle özdeşleşmeyi sadece tekinsiz durumlar yaratıldığında kurarız. Bu özdeşleşme rahatlama değil, rahatsız olma üzerinedir.

Haneke filmlerinde, ailenin korunaklı ortamının, hangi koşul ve durumlarda tekinsizleştiğini göstermeye çalışırken, seyirciye de hayata dair sorular sordurur. Modern toplumlarda bireylerin çoğu kez sahip olduğu statükoyu korumak ya da onu yok etmek için ne kadar ileri gidebileceğini gösterirken, aynı zamanda seyirciyi provoke etmektedir.

Bu çalışma, Freud'un 1919 yılında tekinsizlik üzerine yazmış olduğu makaleden yola çıkarak, Haneke'nin filmlerinde tekinsiz olanın ne olduğunu Modern toplumlardaki burjuva ailenin konformist yapısını baz alacak; Benny’nin Videosu, 7. Kıta ve Saklı filmleri üzerinden açıklamaya çalışacaktır.

Anahtar Sözcükler: Aile, tekinsiz, şiddet, inkar, yüzleşme, ikiyüzlülük, sinema

\section{Modern Family’s Uncanny Moods in Michael Haneke's Films}

\section{Abstract}

Haneke is undoubtedly one of the most controversial directors of contemporary cinema. In his films, he asks questions about how modern individuals are absorbed into their work-oriented lives, alienated and over-individualized in bourgeois society based on capital. As alienation and inward isolation isolate the individual, he tries to understand how the alienated individual perceives the existence and threatening behaviors of "the other". To understand the behavior of the individual, he examines the most protected area of modern society and cinema, i.e.the lives and behavior patterns of middle class bourgeois families, and focuses on how "the uncanny" takes place in a rather sheltered family environment. In his movies, families often become victims or actors of violence, strengthening the uncanny sense in the family environment and creating fear and anxiety. The audience that feels insecure in everyday life will naturally feel uncomfortable when they see in Haneke's films.

Haneke makes the audience ask questions about life as he tries to show under what conditions this sheltered family environment becomes uncanny. In his films, he both shows how far individuals in modern society could go to protect or to destroy the status quo and provokes the audience.

Based on Freud's 1919 dated article on "the uncanny", this study tries to explain what uncanny is in Haneke's films and how it affects the conformist structure of the family via the films; 7. Continent, Benny's Video and Cache.

Keywords: Family, uncanny, violence, denial, confrontation, hypocrisy, cinema 
"Esas utanç, kötülüğü icra eden insanlara değil, onu görmemek için gözlerini kapayanlara ait.” M. Haneke (Cieutat, Rouyer, 2014: 193)

\section{GíRiș}

Modern birey, yaşam biçimini toplumun isteklerine uygun şekilde, yani belirli otomasyon kurallarına göre şekillendirmiştir. Bu yaşam biçimi içerisinde birey, toplumsal uzlaşmayı sağlamak adına modern toplumların suçlarını ve sistemin tıkanıklıklarını görmezden gelmeyi en büyük erdem saymaktadır. İki yüzlülük, inkar ve konformizm, günümüz toplumlarının en belirgin özellikleri olduğu için Haneke'nin sineması seyirciyi, alışkın olduğu konformizmi bozmamak adına çoğu kez görmezden geldiği ırkçılık, cinayet, intihar, tecavüz gibi sorunlarla yüzleştirir. Haneke filmleri çekici olmak yerine sorgulayıcı, rahatsız edici durumlarla örülüdür. Bu nedenle seyirci Haneke filmi izlerken kendisini sürekli tekinsiz bir ortamda ve rahatsız hisseder. Üstelik bu tekinsizlik durumu, en güvenilir kabul edilen aile ortamında yaşanır.

Tekin sözcüğü Almanca'da, "heimlich, heimelig, eve ait olan, yabancı olmayan, bildik, evcil, candan, dostça, eve ya da aileye ait olan ya da ait" (Freud, 2016: 328) sayılmasına karşın Türkçede tekinsizin sözcük anlamı uğursuz ve güvensiz olandır. Toplum tarafından tehlikeli sayılan ve üzerine konuşulması sakıncalı olan tabulardır. Güçbilmez'in de dediği gibi "örtülü kalması gerektiği halde açığa çıkmış her şeydir" (Güçbilmez, 2005:4). Hem Türkçede hem de Almanca'da tekinsiz ${ }^{1}$ sözcüğü güvenilir olmayan, gizli kalması gerekenin açığa çıkmasından kaynaklanan belirsizliğe vurgu yapmaktadır. Bu belirsizlik alanı Freud'a göre korku ve kaygı yaratmaktadır.

Tekin sözcüğünün Almanca karşılığı aileyi yani güvenli alanı işaret ederken, tekinsiz sözcüğü güvenilir olmayanı ve belirsizliği içermektedir. Aile herkes tarafından bilinen en tekin ve kutsal sayılan toplumun en küçük kurumdur. Oysa Freud "Tekinsiz" makalesinde fazlasıyla bildik olanı tekinsiz olarak tanımlamaktadır. Bu çalışma fazlasıyla bildik olan aile kavramının tekinsiz hallerini Haneke'nin filmleri üzerinden Modern toplumun statükocu yaklaşımı içinde açıklamaya çalışacaktır.

“Tekinsizin özellikleri, Frud'un korku alanı diye terimleştirdiği olgu anlamında, gerçek korkudan ziyade kaygının, görünenden ziyade zihinde yer edinen özellikleridir. Freud'un ifadesiyle 'tekinsiz, gizli bir biçimde fazlasıyla bildik bir şey olduğu için tekinsizdir. Onun baskı altında olmasının sebebi budur." (Rodley, 2013: xiii)
Burjuvazinin, modern aileyi ve aile ilişkilerini kutsayan yapısını eleştiren Marks gibi Haneke de filmlerinde kutsal sayılan aileyi merkeze alır; eğitim, televizyon ve modern şehirli yaşamı ve konformizmi, modernizmin kurumları üzerinden eleştirir. Aile ilişkilerini, tekinsiz kavramı üzerinden yeniden tartışmaya sunar. Haneke, filmlerinde ailelere kendilerini tekinsiz hissettirecek bir olay yaşatır. Tekinsizlik hissi, ailenin huzurunu kaçıracak ve artık hiçbir şey eskisi gibi olmayacaktır.

Tekinsiz olanın aile içinde yaşanıyor olması, hem tezatlık yaratır hem de son derece rahatsız edicidir. Çünkü aile her zaman güven duygusunun ön plana çıkarıldığı kurumdur. Ailenin ya da aile bireylerinin güvenilir olmayışı ise toplumlarda huzursuzluk yaratır ve gizli kalması gerekenin açığa çıkmasından kaynaklanan belirsizlik, tedirginlik nedeni olarak karşımıza çıkar. Dolayısıyla tanıdık bildik olanın, ya da öyle sandığımız bireylerin, tekinsiz olabileceği gerçeği ürkütücüdür.

Haneke'nin filmlerinde sürekli karşımıza çıkan ırkçılık, cinayet, tecavüz, nedensiz şiddet ve intihar gibi olay ve durumların toplumlar ya da bireyler tarafından sürekli baskılanmasının, yok sayılmasının sonunda, gün gelip dışarı çıkmasının yarattığı tekinsizlik halleri aile içinde yaşandığında, durum daha da karmaşıklaşır ve aile ilişkilerini alt üst eder. “Tekinsiz, tanıdık olanı tanıdık olamayana dönüştürmekte, çok açı bir şekilde bildik olan şey içinde rahatsız edici bir bildik olmama hali ortaya koymaktadır.” (Rodley, 2013: xiii)

Aile toplumun mikro yansımasıdır görüşünden yola çıkarsak, Haneke de toplumun yaşadığı huzursuzluğu, içinde yaşadığı güvensizliği, suçluluk duygusunu, yabancılaşmayı ve sürekli olarak hissettiği korkuyu aile üzerinden yansıtır. Haneke filmlerindeki aileleri "tekinsizlik kapladığında artık kendini "yuvasında” gibi hissedemez; huzuru kaçmıştır bir kez, baktığı şey ona yabancıdır artık ya da en azından ona öyle görünür” (Güçbilmez, 2003, 27). Huzurları kaçtığında ise ne yapacakları belirsiz tekinsiz bireylere dönüşürler. Bu nedenle Haneke ailelerin sorunlarını çözme yöntemleriyle ilgilenir. Aileden yola çıkarak toplumu sorgular ve bunu insanın sığınağı olan steril evlerin içinden, dehşet öyküleri anlatarak yapmayı başarır. Yakın Plan Haneke kitabında (Assheuer, 2013: 79) Haneke neden ailelerle ilgilendiğini şöyle açıklar:

“Klasik küçük aileyle ilgileniyorum, çünkü bu klasik orta sınıf ve bunlar esas olarak sinemaya giden kesim. Çünkü bunlar toplumumuz açısından tipik... Aile, bu toplumda yaşanan diğer şeylerden daha üst derecede yıkımların 
yaşandığı bir yer değil. Krizler model teşkil etmeleri açısından aile üzerinden daha rahat anlaşılır. Aile, içinde yaşadığımız toplumun yansımasıdır; şifredir”.

Bu çalışma Haneke'nin filmlerine konu edindiği modern burjuva ailelerin, "yaşadığımız toplumun yansımasıdır; şifredir”, cümlesi bağlamında tekinsiz kavramı üzerinde durmaktadır. Bu çalışma özellikle burjuva ailesinde, burjuva bireylerin statükolarını korumak adına nasıl tekinsizleştiklerini Haneke'nin 7.Kıta, Benny'nin Videosu ve Saklı filmleri üzerinden seyirciyi baz alarak açıklamaya çalışacaktır.

\section{Modern Toplumlar, Tekinsiz Aileler}

Tekinsiz durumlar kendiliğinden ortaya çıkmaz. Bir durum ya da koşul sonucu oluşur. Yani, "tekinsiz bir deneyim ya bastırılmış olan çocukluk karmaşaları bazı izlenimlerle bir kez daha canlandırıldığında ya da aşılmış olan ilkel inançlar bize bir kez daha doğrulanmış göründüğünde ortaya çıkar" (Freud, 2016: 347). Freud'un ‘bastırılmış olanın geri dönüşü’ şeklinde açıkladığı bu kavramdaki geri dönüşten anlamamız gereken, bildik ya da tanıdık olanın dönüşerek farklı bir kimlikte karşımıza çıkmasıdır. Normal şartlarda bu dönüşümler herhangi bir belirsizlik ve korku yaratmamasına rağmen bastırılmış olanın geriye dönüşü, endişe ve korku yaratmaktadır. Freud bu durumu "tekinsiz, korku yaratan şeylerin eskiden beri bilinen ve yabancı olmayan bir şeye geri uzanan türüdür” (Freud, 2016: 326) diyerek açıklar ve geçmişten gelen bir sır ya da unutulması gereken bir olayın yeniden ortaya çıkmasından kaynaklanan ve var olan statüyü tehdit etmesi halinde ortaya çıkan korkudan bahseder. Haneke'nin Saklı filminin konusu, Freud'un bastırılmış olanın geri dönüşünden kaynaklanan tekinsizlik üzerine kurulmuştur.

Aile içinde tanıdığımızı sandığımız kişinin bir olay ya da durumla, yabancıya dönüşmesi tedirginlik yaratacağı gibi, ortaya çıkan beklenmedik sonuç karşısında dehşete kapılırız. Çünkü korunaklı bir kale olarak algılanan ailenin içinde ortaya çıkan bu yeni durum, belirsiz ve yok edici bir güç olarak algılanır. "Yabancıyı kabul etmeden buyur etmek, yabancıyı konuk etmeksizin konuk etmek, ne var ki zaten içeri girmiş (das Heimliche-Unheimliche), bize bizden yakın bir yabancının hemen yanı başımızda bulunması, tekil ve kimliği bilinmez bir güce sahiptir” (Derrida, 2001: 260). İşte bu gücün neye dönüşeceği konusundaki belirsizlik ürkütücüdür ve genellikle de görmezden gelinir. Benny'nin Videosu filminde Haneke, ailenin içinde yabancıya dönüşen oğullarından bir haber olan burjuva ailenin içine düştüğü tekinsiz durumu gösterir.

Rodley (2013: xiii) tekinsiz kavramını, modernizm sonrası büyük şehirlerin oluşmasının bir sonucu olarak görür; "insanlar doğadan ve geçmişten koparıldıklarını hissetmeye başladıklarında hastalıkla, ruhsal rahatsızlıklarla özellikle mekânsal korkularla birlikte gelen modern kaygı haline gelmiştir" diyerek modernizmi işaret eder. Modernizmle birlikte bireylerin yabancılaşması, iletişimsizleşmesi ve toplumların tüketim toplumlarına dönüşmesi, tekinsiz durumların artmasına da neden olmuştur.

Marks ve Engels, modern toplumların burjuva toplumu olduğunu ve tüm toplumsal örgütlenmenin sermaye odaklı olarak yeniden tasarlandığını, bundan en çok etkilenen kurumun ise aile olduğunu, bu yapı içinde kendini yeniden tanımlarken, aile ilişkilerinin de sermayeye odaklandığını belirtmişlerdir (Marx ve Engels, 2009). Bu durumdan aileler de oldukça kötü etkilenmiştir.

Marksist öğretiye göre aile, özel mülkiyetin temeli olduğu için bu kurum kapitalizmin temel taşlarından biridir. Özel mülkiyetin miras yoluyla geçmesi gerekliliği ise ailede tek eşliliği zorunlu kılmıştır. Böylece modern aile, sermayenin ve ekonomik ilişkilerin en yoğun yaşandığı kurum haline gelmiştir (Engels, 2003).

Kapitalizm modern aileyi, tıpkı Engels'in açıkladığı gibi, özel mülkiyetin temeli olarak algılar ve içinde bulundurduğu her türden çelişkiyi ve eleştiriyi dışında tutmak için kutsar. Aile içinde yaşanan her türlü felaket, yine aile içinde sonuçlandırılacak, ailenin varlığı ve bütünlügüü böylece devam edecektir. Dışarıdan gelen her türden tehdit, yasal olmayan yollarla bertaraf edilebilir çünkü burjuva ahlak anlayışına göre aile kutsaldır.

Oysa ki "toplum temel kurumlardan, her şeyden çok aile aracılığıyla nevrozlar yaşar ve kendini bireysel kişiliğe yerleştirir” (Brown, 1989: 43). Modern toplumda birey, "sistemin isteklerini yerine getirmek için yüklendiği toplumsal rollerle özdeşleşmeyi mutluluk sayarken ... bir başka mutsuzluğa sürüklenmiştir; okumak, çalışmak, kazanmak, hükmetmek insanın yalnızca başka insanlardan değil, kendi içindeki insan yanından, içindeki insanlaşmış doğadan da uzaklaşmasına neden olmuştur" (Brown, 1989: 11). Böylece kendinden ve doğadan kopan yalnızlaşan insan, özünü kaybetmiştir. Bu ne- 
denle sorunlarla baş ederken etik ya da ahlaki değerleri değil, kendi çıkarları doğrultusunda hareket etmeye zorlanmıştır.

Fidan Eroğlu, Gündelik Faşizmler: Modern Burjuva Toplumunda Kötülük Ve Gündelik Yaşamda Kötülüğün Yeniden Üretimi (2014) başlıklı yüksek lisans tezinde bu durumu burjuva toplumunun duyarsızlığı ile açıklar:

“Çünkü böylesine bir hayatı yaşarken, cinnetler, cinayetler, kişilik özelliği olarak kabul edilen sinir hastalıkları, tutarsızlık, sevgisizlik, acımasızlık, çıkarcılık, rekabet ve kazanma hırsıyla birlikte ayakta kalabiliyoruz. Bütün bunlar neoliberal normativitenin bize telkin ettiği yaşam biçimini sürdürebilmek için deneyimlemek zorunda olduğumuz gündelik pratiklerdir ve bu pratikler neoliberal öznelliğin içeriğini oluşturan değerler sistemidir. Yıkıcı bir biçimde ölümüne yaşayabilmek, değerlerin birbiriyle bu denli çatışabilmesi, mutluluğun acımasızlıkla bu denli iç içe geçmesi, buna uygun davranılması ve bu hayatı bir gün veya belirli bir zaman değil sonsuza kadar sürdürmeye çalışmak büyük bir güç ve dinamizm gerektirir” (Eroğlu, 2014: 7).

Modern burjuva ailelerle ilgilenen Haneke’ye göre “İstediğimiz hayatı yaşamıyoruz. Kendiliğinden oluşan zorunluluklar sebebiyle ne istediğimizi hakikaten unuttuk" (aktaran: Assheuer, 2013:49). Bu nedenle mota mod hayatlar yaşayan otomat bireyler haline gelen ve tüketim nesneleriyle çevrili dünyasında kendine ait olanı bulma konusunda zorluk çeker. Yenilik yerine sürekli kendini tekrarlayan hayatlarında amacını kaybettiğinde de kolaylıkla yaşamlarından vazgeçebilirler. Foucault göre modern toplumlarda iktidarlar bireye belli kimlikler vererek kategorize ederek gündelik hayatlarına müdahaleyi daha kolay hale getirir.

“İktidar biçimi bireyi kategorize ederek, bireyselliğiyle belirleyerek, kimliğine bağlayarak, ona hem kendisinin hem de başkalarının onda tanımak zorunda olduğu bir hakikat yasası dayatarak doğrudan gündelik yaşama müdahale eder” (Foucault, 2014: 63).

Böylece kendine belirlenen kimliği doğrultusunda hareket edecek, elde ettiği statüyü korumak adına kendisine kolaylıkla ters düşebilecek, gündelik hayat içindeki değerler sistemi çerçevesinde hareket edecektir.

\section{Haneke'nin Benny'nin Videosu, 7. Kıta ve Saklı Filmlerinin Te- kinsiz Aileleri:}

Haneke'ye göre burjuva ailelerin benzer tutum ve davranışları onları aynılaştırmaktadır. Bu nedenle filmlerindeki aile fertlerine hep aynı isimleri verir; bütün kadınlar Anna, erkekler ise Georges'tur. Çekirdek aileyi temsil ettikleri için tek çocuklarının adı ise Eva'dır. Anne ve Georges genellikle burjuva dünyasının tecrit edilmiş şehirlerinde, burjuva tarzı evlerinde yaşarlar. Bu ailelerin ortak özellikleri monoton hayatları, iletişimsizleri ve başlarına gelen sıra dışı olaylardır. Bu aileler şiddetin bazen aktörleri, bazen de kurbanları olurlar. Anne ve Georges'u gündelik hayatlarında karşılaştıkları sorunları, kendi yöntemleriyle çözmeye çalışırken izleriz; çözümleri bazen intihar (7. Kıta), bazen de cinayettir (Benny'nin Videosu); ama mutlaka şiddet içerir. Sebepsiz bir şiddet temel sorun olurken (Ölümcül Oyunlar), bazen de insanın geçmişinden kaçıp, kurtulamadığı bir intikam duygusu (Saklı), ya da bilinmeyen bir nedenle cinayet işleyenin öznesi (Benny'nin Videosu) veya yaşlılığın doğal şiddeti ( $A s ̧ k$ ) oluverir. Haneke filmlerinde şiddetin sunumu genellikle beklenmedik bir anda gerçekleşir ve seyircide şok yaratır.

Şiddet ve suç, aile kurumu için tekinsiz eylemlerdir. Şiddetin kim tarafından uygulandığı tekinsiz tanımını değiştirmese de sonucu belirler. Şiddet aile üyeleri tarafından uygulandığında, daha tedirgin edicidir ve sonucu daha tartışılır hale getirir. Haneke'nin modern aileleri, en güvenli ve huzurlu mekânları olan evlerinde, tekinsiz bir durumla karşılaştıklarında alışkanlıklarını ve yaşamlarını sürdürmek adına kolaylıkla cinayet işleyebildiklerine, kendilerini tehdit eden tekinsizliği yok etmek için ahlaki değerlerini yok sayabildiklerine tanık oluruz. Benny'nin Videosu, 7.Kıta ve Saklı filmlerinde toplumda var olan şiddeti toplumun kendisinin yarattığın göstermeye çalışır. Toplumun duyarsızlaşmasını hızlandıran medyayı her filminde eleştirir.

Genelde Haneke filmlerinde aileleri günlük yaşamlarında her şey yolunda giderken izleriz, ancak aileyi tehdit eden bir olayla düzen bozulur. Bu tehdit ya geçmişte sakladıkları bir sır ( $S a k l ı)$, ya izlediği şiddet videolarından etkilenen ve sevgisiz büyüyen bir ergenin sebepsiz cinayeti (Benny'nin Videosu), ya da sistemin dayattığı "kurmaca” dünyanın yalanlarından, saçmalığından ve süregelen aynılığından sıkılan, kendisiyle birlikte ailesini de yok eden baba (7.Kıta) olsun, suç ve şiddet içerir. En korunaklı mekanlar olan evler, Haneke'nin filmlerin- 
de aileyi koruyan, kapatan hapishanelere dönüşür. Hapishaneye dönüşen ev vurgusu, 7.Kıta, Saklı, Benny'nin Videosu, Ölümcül Oyunlar ve Aşk filmlerinde de vardır. Ev ortamını sevgiden ve sevecenlikten uzak, donuk ve aynı şekilde tekrarlanan bir otomatizm olarak sunduğu için, hapishaneleri çağrıştırır. Haneke filmlerinde modern burjuva ailelerin, çoğu kez statükolarını koruma güdüsüyle hareket ettiklerinden dolayı bir sorunla ya da tehditle karşılaştıklarında, saldırganlaştıklarını, kolaylıkla yalan söylediklerini ve çoğu kez şiddete başvurduklarını görürüz. "Haneke sinemasının şiddete bakışı, tam da bu tehlikeli duyarsızlaşmayı bertaraf etmek üzere, seyircinin toplumsal, siyasal ve medyatik düzeyde kök salmış farklı şiddet biçimlerini algılamasını ve kendisinin de dahil olduğu tahakküm ilişkilerini yeniden sorgulanmasını sağlama çabası üzerine kuruludur” (Cheviron vd, 2014:110). Toplumda görmezden gelinen her tür olumsuzluğun, günün birinde kendisini de bulacağını tekinsiz bir şekilde anlatır.

7. Kıta filminde şiddet anne babası tarafından, küçük kızlarına ve kendilerini yok etmek için uygulanır. Bu filmde aile şiddetin hem kurbanı hem de failidir. Eva için şiddet, en tanıdık bildik ve en güvendiği ailesinden gelir. Anne ve babası da yaşamlarına son vererek, şiddeti kendilerine uygularlar. Film bittiğinde, bu ailenin neden hayatlarını yok ettiğini anlamlandırmaya çabalarız.

Benny'nin Videosu filminde tekinsiz olan şiddet üç katmanlıdır ve aile fertlerinin tümünü kapsar. Şiddete meyilli olan ergen Benny, sadece öldürmenin nasıl bir duygu olduğunu deneyimlemek için yaşıtı bir kızı öldürmekten çekinmez. Bu olayda tekinsiz olan, kıza göre Benny'dir. Benny ile hoş vakit geçireceğini düşündüğü için eve gelmiş ve anlamsız şekilde ölmüştür. Filmde ikinci tekinsiz durumu ve şiddeti Benny'nin ailesi yaratır. Oğullarının cinayet işlediğini öğrendikten sonra Anna ve Georges'u, cesedi yok etme planları yaparken görürüz. Hayatlarını ve statükolarını koruma kaygısıyla hızla çözüm üretirler. Ne ölen kızı ve ailesini düşünürler, ne de oğullarının neden böyle bir şey yaptığını tartışırlar. Ölen kız Benny'nin babası tarafından parçalanarak yok edilecek, böylece sorun ortadan kalkacak ve hayatlarına kaldıkları yerden devam edeceklerdir. Ancak bilmedikleri Benny'nin her şeyi kayıt altına almasıdır. Benny sevgisiz bir ortamda büyümüş bir ergendir. Nedensiz cinayet işlediği gibi, nedenini çok anlamadığımız bir şeklide ailesini polise ihbar ederek, anne ve babası için üçüncü tekinsiz durumu ve şiddeti yaratır. Benny ailesinden özür diler ve film biter. Ama seyirci için film tam da bu sonda başlar. Seyirci kendisinin de içinde olduğu toplumsal ilişkilerin baskıcı yanını sorgulamaya itilir. "Haneke, filmlerinde seyirciyi uyaran, sarsan, kendi anlamlarını yaratması ve özeleştiride bulunması yönünde onu sürekli teşvik eden, yani seyirciyi filme dahil eden bir yönetmen olduğundan, söz konusu sancılı süreci, filmi izleyerek bizzat seyircinin kendisi de yaşar" (Cheviron vd, 2014: 125) Haneke seyirciyi sürekli vicdanı ile yüz yüze getirir. 'Acaba onun yerinde ben olsam ne yapardım?' sorusunu sordurur. Seyirci kolayca unuttuğu, görmezden geldiği bireysel ya da toplumsal şiddetin bir gün kendisini de bulabileceği tekinsizliğinin, kaygı dolu dünyasında bulur kendisini. Seyirciyi çoğu kez öfkelendirip çileden çıkartan ve istemediği, görmezden geldiği konuları düşünmeye zorlayan Haneke "onları eylemin suç ortağı yapıyorum ve onları da bundan dolayı suçluyorum. Bu hiç hoşa gitmiyor. Şiddeti tüketmenin aynı zamanda yardaklık etmek de olduğunu anlamak istemiyorlar" (Asshauer, 2013: 67) der.

Burjuva aile, tekinsiz durumlarla karşılaştığında bizatihi kendisi tekinsiz olmayı başarır, ancak sonuçlarına katlanamaz. Saklı filminde Georges suçluluk duygusuyla baş edemez, uyumak için uyku hapı alır. Benny'nin annesi vicdan azabından ağlayarak kurtulmaya çalışır. 7. Kıta filminde ise intihardan önceki günlerinde anne baba, kızlarına ve kendilerine ziyafet verirler. Bu durumu Haneke şöyle açıklar: "Hepimiz liberalizmin tutsağıyız ve kaybetme korkusu her gün bizimle. Bazı şeyleri bilmemize rağmen dile getirmekten başka bir şey yapamıyoruz. Rahat uyuyabilmek için kendimize yalan da söylüyoruz" (Assheuer, 2013: 47).

Haneke insanın salt iyi ya da salt kötü olduğuna inanmaz. Özellikle konu burjuva bireyler oldu mu, çıkar ilişkisi içinde hem iyi hem de kötü aynı anda oluverir. Ancak yönetmen özellikle burjuva bireyin suç işleyen, şiddet uygulayan karanlık ve tekinsiz yanıyla ilgilenir.

Bu bölümde Haneke'nin filmlerindeki tekinsiz kavramı, Benny'nin Videosu, 7.Kıta ve Saklı filmleri üzerinden açılanmaya çalışılacaktır. Bu filmlerin en önemli ortak yanı gerçek olayları referans almalarıdır. Üç filmde de çekirdek burjuva aileler vardır ve ailenin varlığını tehdit eden bir olay karşısında, tekinsiz durumlar yaratırlar. Duygusal Buzlaşma Üçlemesi (Kent Üçlemesi) olarak tanımladığı 7.Kıta ve Benny’nin Videosu filmleri üçlemenin ilk iki filmidir. Modern toplumların kentlerinde yaşanan iletişimsizliğin altını çizmek için Haneke, duygusal buzlaşma kavramını kullanmıştır ve duygusal buzlaşmanın 
aile gibi duygu bazlı bir kurumunda yaşanmasının çelişik durumuna vurgu yapar.

Benny'nin Videosu (1992) filminde Haneke, 1990'ların modern dünyasını her yönüyle sarıp sarmalayan televizyonun giderek artan olumsuz etkisinin sonuçlarıyla yüzleştirir. Savaş, tecavüz ve cinayetleri, gündelik yaşamın rutini gibi algılayışımızın sonucunda şiddetin evlerimize kadar, nasıl doğal bir olaymış gibi girdiğini gösterir.

Televizyon gibi gündelik yaşamımıza hızla giren, video oyunları, bilgisayarlar ve video kameraların bilinçsiz ve özensiz kullanımının yeni yetme ergen bir çocuğun hayatını nasıl etkileyebileceğine şahitlik ederiz. Medyayı şiddetin temsilcisi olarak gören Haneke,

"Ben çoğu zaman, medyanın şiddet temsilinin başlıca anahtarı olan televizyon ile yakından ilgileniyorum. Benim, kolektif gerçeklik kaybımız ve sosyal uyum bozukluğumuz olarak gördüğüm; daha genel ve büyük bir kriz. Yabancılaşma çok karmaşık bir sorun fakat televizyon kesinlikle bu sorunu içermektedir” (Kırmızı, 2017)

Haneke, Benny'nin Videosu filmini gazete haberlerinden esinlenerek yapmıştır; "O sıralar gazetelerde çok sayıda, ergenler tarafından işlenmiş cinayet vakasına rastlıyordum ve hemen hepsi niçin böyle bir şey yaptıkları sorusunu, 'nasıl hissettirdiğini merak ediyordum' diye cevaplamakla yetiniyordu. Bu beni çok sarsmıştı ve konu üzerinde kafa yormaya başladım” (Cieutat § Rouyer, 2014: 187).

Haneke gazetede okuduğu ergenlerin neden cinayet işledikleri sorusuna "bilmiyorum sadece nasıl bir şey olduğunu merak ettim” cevabını filmde oyuncusu Benny’e verdirerek gerçek dünyanın uzantısını filme taşır. Benny videodan bir domuzun ölüm anını video oyunu gibi ileri geri sararak aynı sahneyi defalarca seyrettiği gibi, genç kızın ölüm anını da videoya çekerek gerçek ile oyun arasındaki ayırımı yitirir.

Baudrillard büyüleyici imajlarla insanı şaşkına çeviren medya konusunda Modern insanı uyarmıştır. Baudrilard Simulasyonlar kitabında "hipergerçeklikte gerçek ve hayali olanın birbirine karıştığını ve estetik büyülenmenin her yeri sardığını belirtir” (Featherstone, 1996: 120). Böylece gerçek olan ile hayali olanın ayrımı ortadan kalmıştır. Haneke'ye göre de tekinsiz olan bu durumu medya yaratmıştır.

“Gösteri dünyasının dönüştürdüğü şiddeti gerçek olarak algılayabilirsiniz. İstediğiniz kadar başkalarına vurma- mak gerektiğini söyleyin, çocuk buna kolay kolay inanmayacaktır; çünkü televizyonda habire vurdu kırdı görüyor; üstelik bunların seyri bayağı keyiflidir de. Böylece bakış deforme oluyor. Normal şartlarda yaşıyorsanız, buna bir bağışıklık geliştirebilir ve sonunda neyin ne olduğunu anlayabilirsiniz. Fakat duygusal ve toplumsal açıdan baskı altındaysanız, kurgu ile gerçeklik arasındaki sınırı ayırt etmekte zorlanabilirsiniz" (Cieutat §Rouyer, 2014: 189).

Haneke video kamerayı filmin anlatımında ikinci bir katman olarak kullanır. Benny'nin genç kızı öldürme anını video kameranın monitöründen izleriz. Benny'nin anne ve babası da oğullarının işlediği cinayeti, video kameradan hiç yorum yapmadan film gibi seyrederler. Böylece video kamera estetik bir unsur olarak da filme dahil olur.

Benny ailesi tarafından öldürülen bir domuzun öldürülme anından etkilenip, öldürmenin nasıl bir şey olduğunu anlamak istemektedir. Video dükkânında tanıştığı bir kızı evine davet eder ve kıza domuzun öldürülme sahnesini izletir. Kız izlediği sahneden Benny kadar etkilenmez. Benyy kızı daha fazla etkilemek için domuzu vuran silahı getirir, kızın silahı kullanmasını ister. Kız silahı kullanmayı ret edince aralarında çocukça inatlaşma yaşanır. Kız iki kez Benny’e ‘korkak' der ve bunun sonucunda Benny tarafından öldürülür. Seyirci bu ani ölüm karşısında şaşırmıştır. 0 kadar nedensiz ve anlamsız bir şiddete maruz kalır ki, karşısındaki tekinsiz olanın ergen olmasına rağmen oldukça soğukkanlı tavırları karşısında daha da tedirginleşir. Haneke bu durumu mahrumiyet ve merhamet duyguları üzerinden şöyle yorumlar:

“Böyle davranan biri sıcak bir aile ortamından çıkamaz. Bu tür vakaları tahlil eden yığınla psikoloji makalesi var: esasen sapkın olmayan, fakat şefkat duygusundan mahrum insanlar söz konusu. Bunlar aynı Benny gibi, en ufak bir pişmanlık duymadan öldürebiliyorlar. Geçmişlerinin üzerine biraz eğildiğinizde hemen hepsinin çok soğuk, duygusuz ortamlarda büyüdüklerini görüyorsunuz. Mahrumiyetini çektikleri şefkat, onların da merhamet duymalarını engelliyor” (Cieutat,Rouyer, 2014: 188).

Benny de aile ortamında oldukça soğuk ve mesafelidir. Ailenin kollayıcı ve sıcak ortamı yerine duygulardan uzak ve iletişimsiz bir hayatı vardır. Şefkatten mahrum yetişmiş olan Benny'den, ne genç kıza ne de ailesine merhamet duyması beklemez. Aile ne vermiş ise onun karşılığını alır. 


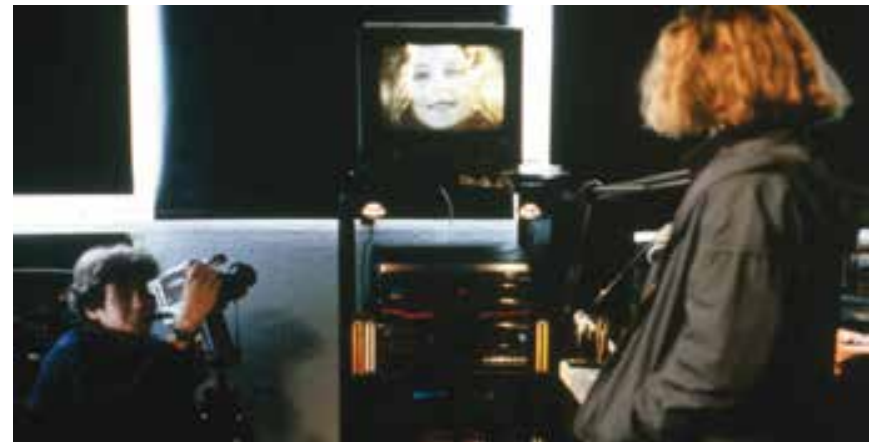

Fotoğraf 1. Benny'in Videosu (1992). Benny her şeyi video kamerasıyla çeker.

Benny ilk kurşunu kıza korkak olmadığını kanıtlamak için sıkmıştır. Ancak kız ilk kurşunla ölmez, acıdan bağırmaya başladığında Benny paniğe kapılıp kızı başından vurmakta bir sakınca görmez. Kızın öldüğünü anladığında ise paniklemez. Tüm bu olaylar olurken kamerası her zaman olduğu gibi açıktır ve her şeyi kaydetmektedir. Benny'nin cinayet işlemekten pişmanlık duymayan, soğukkanlı bir katil oluşunu izleriz. Benny'nin rahat tavırlarındaki tekinsizliğine ve genç kızın cesedini sürüklemesine tanık oluruz. Seyirci Benny'nin tavırları karşısında kendisini rahatsız hissetmeye başlar. Hiçbir şey olmamış gibi arkadaşıyla oldukça rahat bir tavırla telefonda görüşmesi ve akşam da gece kulübüne gidip arkadaşında kalması, işlediği cinayetten hiçbir pişmanlık hissetmediğini gösterir. Tavırları ve yaptıklarıyla tekinsizliği daha da arttırmaktadır. Benny ergen olmasına rağmen ortada onu kollayan ve koruyan ailesi yoktur. Genç bir adam gibi hayatını yalnız sürdürmekte, gece kulüplerine gidip sigara içmektedir. Benny cinayetten üç gün sonra ailesine çektiği görüntüleri izletir. Ailesi izledikleri karşısında şok olur ama tepki vermez. Videoyu izlerken Benny'nin 'acıktım' demesi ve Anna'nın kalkıp oğluna yemek hazırlaması, seyirciyi çileden çıkartır. Georges ise sürekli oğluna onları birlikte gören olup olmadığını ya da olayı birine anlatıp anlatmadığını sorar. Olayın nedeni ve sonuçları üzerinde durmaz. Aile oğullarını ve kendi yaşamlarını korumak adına cesetten kurtulmaya karar verir. Georges kızı parçalayacak, Anna ise Benny ile tatile çıkacak ve konu kapanacaktır. Anna ve Georges oğullarının işlediği cinayetin nedenini tartışmaz, yorum dahi yapmaz. Yaşanılması gereken bir hayatları ve korumaları gereken statükoları adına kararlar alır ve uygularlar.

Aile hiçbir şey olmamış gibi hayatlarına devam ederken, Benny’yi çektiği görüntüleri polise izletirken görürüz. Polisler
Anna ve Geogese'u tutuklar. Benny ailesinden özür diler ve film yine şok edici bir sonla biter.

Filmde tedirgin eden, rahatsızlık veren birçok öğeden birisi Benny’nin cinayet işledikten sonra hiçbir şey olmamış gibi hayatına devam etmesidir. Olayı daha da tekinsiz hale getiren şey ise Anna ve Georges'un, Benny'in cinayet işlemesine tepki vermeden kurbanı ortadan kaldırma girişimleridir. Filmin sonunda Benny izleyiciyi şaşırtmaz, vicdan azabından olmadığı belli olan bir tavırla, anne ve babasını polise teslim eder.

Haneke’ye göre üstünü örttüğümüz, görmezden geldiğimiz şiddetin her şekli, bizi kolaylıkla ele geçirmeye hazırdır. 'Anna ya da Georges'un yerinde olsanız ne yaparsınız?' Genelde aileler, aile birliğini sarsacak olayları görmezden gelip, üstlerini örtmek gibi bir tavır içindedir. Bu hayatlarının sekteye uğramasını ve statükolarını kaybetmek istememelerinden kaynaklansa da, görmezden geldikleri her olay, kendi sonlarını hazırlayacaktır.

7. Kıta (1989) filmi de gerçek bir olaydan yola çıkarak yapılmıştır. Bu film diğer filmlerden farklıdır. Modern toplumun kurallarına göre ailenin varlığını tehdit eden, tekinsiz olan, ailenin bizzat kendisi olmuştur. Filmin çarpıcılığı ise hikâyenin gerçek oluşudur. Stern gazetesinde okuduğu bir haberden etkilenerek senaryosunu yazan Haneke filmi için şöyle demektedir:

“İntihar etmeye karar veren bir ailenin, öncesinde bütün mallarını mülklerini nasıl ortadan kaldırdıklarını anlatan o yazı beni çok sarsmıştı. Makalede toplumsal ve psikolojik düzen üzerinden birtakım izahatlar ileri sürülüyordu. Ama benim esas ilgimi çeken, kendilerini yok etmeden önce onları yıkıma götüren maddi dünyayı yok etmeleriydi” (Cieutat § Rouyer, 2014: 169-170).

Modern aileler toplumsal statülerine sahip olurken duygusal ilişkileri sekteye uğramakta ve bu durumu tüketerek gidermeye çalışmaktadırlar. Baudrillard,

"Sadece tüm işlevlerin, tüm ihtiyaçların kar terimiyle nesneleştirilmesi anlamında değil, aynı zamanda her şeyin gösterileşmesi yani her şeyin imgeler, göstergeler, tüketilebilir maddeler olarak çağrıştırılması, kışkırtılması, düzenlenmesi gibi daha derin bir anlamda her şey bu mantık etrafında ele geçirildi” (Baudrillard, 2008: 251).

Demektedir. Anne ve Goerges, burjuva yapısına uygun bir hayat yaşamaktadır. İyi işleri, tüketim nesneleri ile dolu 
evleri ve küçük bir kızları vardır. Dışardan bakıldığında hayattan istediklerini elde etmiş, sorunsuz ve sıkıntısız bir aile izlenimi verirler. Oysa bu ailenin tekrarlanan gündelik hayatlarındaki rutin ve renksizlik filmin en can alıcı noktasıdır. Aile film boyunca açık olan televizyondan şiddet içeren haberleri çoğu kez tepkisiz izler. Televizyon ekranından kendilerine gelen tüm görsel imajlara maruz kalır.

“Çünkü modern insanın sıradan bir gününde deneyime dönüştürebilecek hiçbir şey yoktur. Ne yaşamıyla uzaktan yakından ilgisi olmayan bir sürü haberle dolu gazetesini okumak... ne süpermarkette bolluk ülkesini ziyaret etmek... Modern insan akşamları karmakarışık bir sürü olay karşısında bitkin düşmüş bir halde evinin yolunu tutar" (Laustsen ve Diken, 2010: 133)

Filmde yaşamlarını tek düze bir sisteme kurban etmiş bir burjuva ailenin tüketim toplumu içindeki nesnelerle sarılı dünyalarından çıkışı kendilerini yok ederek bulan modern bir aileyi anlatır. Bu filmde tekinsiz olan modern toplumun dayattığı aynılık, sıradanlık, iletişimsizlik ve yabancılaşmanın sonunda ailenin intihar etmesidir.

Georges ve Anne için, rutin giden hayatlarında yapılacak çok şey, değiştirilecek bir şey kalmamıştır. Filmin tekinsizliği, gündelik hayatlarının kahreden rutinidir. Anne ve Georges, hayatları boyunca kendilerinden geçerek sahip oldukları nesnelerle kurdukları evlerinde, adeta hapis hayatı yaşamakta ve bu durumu değiştirme konusunda isteksiz görünmektedirler. Agamben'e göre modern toplumun tüketim mantığı nesne biriktirmeden geçiyorsa (Laustsen ve Diken, 2010: 133) “kendini geliştirmek mastürbasyondur. Asıl çözüm kendini yok etmektir”. Bu nedenle, yaşamlarını aldıkları kararla sonlandırmak isterler. Bu kararı alırken Anne ve Goerges'u görmeyiz, sadece kararı uyguladıklarına şahit oluruz. Haneke intihar kararından çok, kararı aldıktan sonra elleriyle kurdukları nesneler dünyasını, yine elleriyle nasıl yok ettikleri ile ilgilidir. Filmdeki tekinsiz durum, Georges ve Anna'nın yıllarca çalışıp uğruna kendi benliklerinden vazgeçtikleri eşyalarını, yaşamlarını özenle ve sakince parçaladıkları sahnelerdir. Modern toplumunun düzenine ayak uyarak toplumda nesnelere dönüşmüş bireyler olmak yerine "hayatlarımızdan daha iyi bir şey çıkarmak için her şeyi yıkmamız gerek" (Laustsen ve Diken, 2010: 133) diyerek o güne kadar biriktirdikleri tüketim nesnelerinden kurtulmaya çalışırlar. Özellikle paraların yırtılıp tuvalete atılması sahnesi çok kışkırtıcıdır. Haneke bu aile- nin intiharını anlamlandırmak adına, yaşamları gibi eşyalarını da mekanik bir şekilde tahrip ettikleri sahneyi şöyle açıklar:

"Hikayenin sonunda aile fertleri sahip oldukları bütün eşyaları tahrip ediyor. Ama trajik olan, bunu tam olarak özgürleşmeyi başaramadan yapmaları. 0 güne kadar nasıl yaşadılarsa, eşyalarını yine öyle, aynı mekaniklikle tahrip ediyorlar. Filmin en hüzünlü yanı bence bu... Her şeyi tahrip ettiklerinde bile hiçbir şey değişmiş değil. Maddi dünyaları iç dünyalarını ele geçirmiş çünkü. 0 nedenle de hiçbir şeye yaramayacak olsa da intihar etmekten başka çareleri yok!” (Cieutat § Rouyer, 2014: 173).

Maddi dünyadan vaz geçmişliğin en belirgin göstergesi olan paraları yırtıp klozete atma sahnesini, seyirciyi bilerek rahatsız etmek için çektiğini söyler:

“Bunun insanları şoke edeceğini biliyordum; prodüktörü önceden uyarmıştım. 0 ise balıkların can çekişme görüntülerini daha rahatsız edici geleceği kanısındaydı. Filmin Cannes Festivali'nde, Quinzaine Des Realisateurs kapsamında gösterimi sırasındaki tepkiler beni haklı çıkardı: Paraların imha edildiği sahnede otuz-kırk kişi salonu terk etti. Bunu tahmin ediyordum aslında, çünkü para en büyük tabulardan biri, balıkların can çekişmesinden de çocuğun ölümünden de daha büyük. Her şeyi gösterebilirsin perdede ama bunu asla. Ortaçağ'da haça tükürmenin olduğu kadar kabul edilemez bir davranış" (Cieutat § Rouyer, 2014: 183-184).

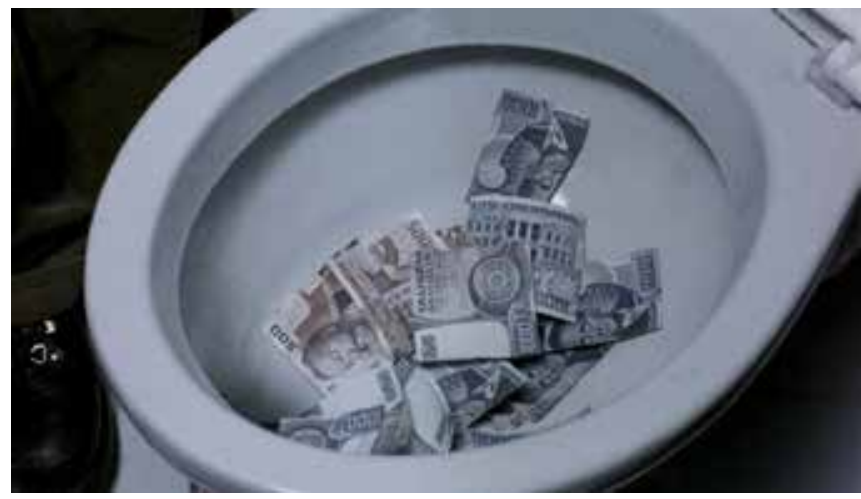

Fotograf 2. 7.Kıta Filmi (1989). Paraları yırtma ve klozete atma sahnesi

Anne ve Georges'un sahip oldukları arasında küçük kızları da vardır ve bu nedenle intihar kararlarına kızlarını da dâhil etmişlerdir. Tekinsizlik, anne babadan geldiğinde durum daha da karmaşık bir hal almıştır. Burjuva ailenin birinci görevi ço- 
cuklarını kollamak ve korumaktır. Oysa bu filmin asıl mağduru Eva'dır. Daha hayatının başında yaşamla doğru bir iletişime geçmeden, ailesinin kendi adına aldığı karar sonucu ölmüştür.

Haneke, gerçekte yaşanmış bu intihar olayını gösterirken, seyircinin de kendi yaşamlarıyla yüzleşmelerini ister. 'Acaba gerçekten başka çareleri yok muydu?', ‘İnsan her şeye sahip olup, sahip olduklarından bu kadar kolay vazgeçebilir mi?'. Gerçek hayattaki Georges'un anne ve babası, oğullarının ailesiyle birlikte intihar ettiğine inanmak istemez. Onlara göre hayatlarını sonlandıracak bir sorunları yoktur. Her şeyleri vardır, güzel bir ev, eş ve çocuk. Olayın intihar olduğuna inanmadıkları için cinayet soruşturması başlatsalar da, dosya sonuçlanmadan kapanır. Maddi dünyanın yasalarına göre bu intiharın nedeninin açıklanması zordur. Haneke filmin sonunda seyirciyi birçok soruyla yine baş başa bırakır.

Seyircinin yeri ve konumu onun sinemasında oldukça önemlidir. Duyarsızlaşan modern toplumun bir parçası olan seyircinin bu tarz kışkırtıcı sahnelerle şok olmasını ve düşünmesi ister ki yaşadığı toplumun kendini dönüştürdüğü hali görebilsin. Bu nedenle seyircisine karşı acımasızdır. Haneke'ye göre filmler manipülatiftir.

"Her film manipülatiftir, izleyicisine tecavüz eder. Soru şu ki: Neden izleyiciye tecavüz ediyorum? İzleyicinin bu tecavüz aracılığıyla düşünceli, entelektüel olarak bağımsız olmasına ve bu manipülasyon oyunundaki yerini görmesine uğraşırım. Onun aklına güveniyorum. En iyi ihtimaliyle, film kayakla atlama gibi olmalıdır. Film, izleyiciye yerden havalanma olanağını vermelidir. Zıplayıp zıplamamaksa ona kalmıştır” (Kırmızı, 2017: 44).

Saklı (2005) filminde eleştirisini yine modern batılı aileye yöneltmiştir ama bir farkla, ırkçılığı, sömürgeciliği ile modern toplumların ikiyüzlülüğünü de konuya dahil ederek eksenini genişletmiştir. Fransa'da kırk yıl önce yaşanmış bir katliamın, toplumdan kırk yıl boyunca nasıl saklanabildiğini ve inkâr edildiğini anlamaya çalışır.

“Arte'de, 17 Ekim 1961 Paris katliamı üzerine bir belgesel izliyor Michael Haneke. Saklı (Caché, 2005) filmi böyle ortaya çıkıyor. Fransız toplumunun katliamla ilgili 40 yıllık sessizliği, katliamla ilgili yayın yasağı ve kendisinin de bütün bunları bir belgeselden öğrenmesi, tarihsel hafızanın bastırılması ile kişisel hatıraların bastırılması arasındaki ilişkiyi irdelemeye götürüyor Haneke’yi... Her milletin kolektif bir suçu, karanlık köşeleri, kara lekele- ri vardır. Ancak Haneke'nin derdi işlenen kolektif suçun hakikatini göstermek, bu hakikati temsil etmek değil, suçun inkârı, inkârın tekerrürü üzerine düşünmektir. Bu evrensel, herkesin kapıldığı, inkârı mümkün kılan çekirdek duyguyla ilgilenir Haneke" (Arslan).

Georges ve Anne oğulları ile yaşayan çekirdek bir burjuva ailedir. Georges başarılı bir televizyon yapımcısıdır, Anna ise bir yayın evinde çalışmaktadır. Bir poşet içinde evlerinin önüne bırakılmış, evlerinin dışardan çekimlerini içeren görüntülerden oluşan kasetler ailenin canını sıkar. Ancak kaset sayısı arttıkça tekinsiz bir durum ortaya çıkar. Kimler tarafından yapıldığı ve bırakıldığı anlaşılmayan kasetler, aile için tehdit oluşturur ve tekinsiz bir durum yaratır. Aile, ötekinin tehdidi sonucunda korku ve sarsıntı yaşar. Filmde düğümler çözülmeye başladığında olanların, 1960’larda Paris'te yaşanılan bir katliam sonrası Georges'un ailesinin, anne ve babası polisler tarafından öldürülen Cezayirli Majid'i evlat edinmek istemesi olayı ile ilgili olduğu anlaşılır. Film 'tarihsel bir gerçeklik şimdiki zamana musallat olursa ne yaparız?' sorusuna cevap arar niteliktedir. 0 yıllarda altı yaşında olan Georges'un kendisine rakip gelen bu çocuğu kabullenemediği, odasını ve ailesini bu yabancı çocukla paylaşmak istemediği için Majid'in evden atılmasını sağlayan yalanlar söylediğini, Anna ile konuşurken öğreniriz. Çocuk Georges, babasının en sevdiği horozunun kafasını Majid'in kestiğini ve sonrada kendisini korkuttuğu söylemiştir. Oysa Majid'e de babasının horozu kesmesini istediği yalanını söylemiş, Majid horozu kesmiş ve bu olay onun yetimhaneye gitmesine ve istemediği bir yaşam sürmesine neden olmuştur.

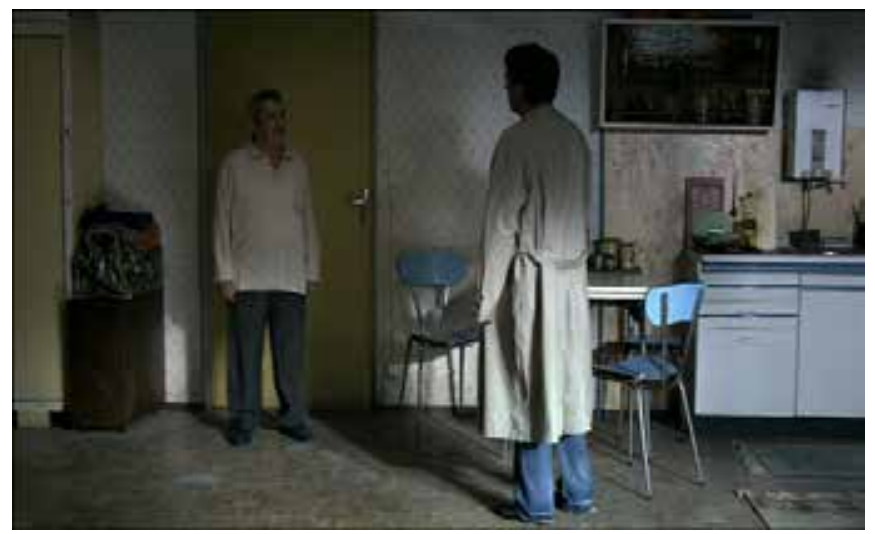

Fotoğraf 3. Saklı Filmi (2005) Georges'un Majid'in evine gitmesi.

Tıpkı Fransızların toplumlarından kırk yıl sakladığı katliam gibi Georges da yıllar önce söylemiş olduğu yalanların 
ve sırların tekinsiz halleriyle kırk yıl sonra yüzleşmek zorunda kalır. Bu tekinsiz bir durumdur. "Tekinsiz bir deneyim; ya bastırılmış olan çocukluk karmaşaları bazı izlenimlerle bir kez daha canlandırıldığında ya da aşılmış olan ilkel inançlar bize bir kez daha doğrulanmış göründüğünde ortaya çıkar” (Freud, 2016: 347). Freud'un 'bastırılmış olanın geri dönüşü’ şeklinde açıkladığı bu kavramdaki geri dönüş, Majid ile vücut bulmuştur. Majid ile birlikte hem ona hem de ailesine söylediği yalan / sır yıllar sonra ortaya çıkacaktır. Belli bir toplumsal konumda olan Georges'un baskılanmış geçmişi, şimdiki zamanı ele geçirdiğinde geçmişin korkularından korunacak gücü kendisinde bulamaz. Majid’le yüzleşmeye gittiğinde, Majid Georges'a 'sana bir hediyem var' deyip boynunu (tıpkı horoz gibi) kesip intihar eder. Georges, nedeni kendisi olan ve önünde gerçekleşen intihar anında ne yapacağını bilemez. Sonrasında intihar olmamış gibi davranmayı seçer, sinemaya gider. Kolektif kötülüğün bir parçası haline gelmiş olan George (seyirciler) için inkâr en kolay çözümdür.

“Bu Georges’u kötü biri mi yapmaktadır? Hayır. Zaafları da, yalanları da, inkârı da, yüzleşme çabaları da samimidir Georges'un. Bütün bunlar, daha çok Georges'la, yalan söyleyerek hayatını değiştirdiği Majid'in arasında sadece ikiye ayrılmış bir geçmiş değil, coğrafi, toplumsal ve duygusal olarak da hukuksuzluk içeren derin bir yarığın, kırılmanın olduğunu anlatabilmek içindir. Bu, Georges'u kolektif kötülüğün bir parçası yapmaktadır. Haneke, Georges’ları, kendi üzerine düşünmeleri, hayatlarını yalanlarıyla değiştirebildikleri Cezayirli Majid’ler karşısındaki ayrıcalıklı konumlarını görebilmeleri için kışkırtmak, rahatsız etmek ister. Çünkü Georges'lar suçluluk duyarken inkâr da etmekte, korku ve endişe duymanın yanında öfkeli bir biçimde kendilerini savunmaktan vazgeçmemektedir. Hatta çok defa kendilerini kurban gibi görürler, iyi ve masum olduklarına dair güçlü bir inançları vardır” (Arslan).

Eve geldiğinde Anna'ya olayı anlatır. Benny'in Videosu filminde olduğu gibi Anna da Georges'a onu eve girerken birinin görüp görmediğini sorar. Önemli olan olay değildir, önemli olan Georges'un başkası tarafından görülmemesidir. Eğer başkaları Georges'u görmüş ise yaşamları alt üst olacak, o güne kadar elde etmek için çabaladıkları her şey boşa gidecektir.

Saklı, toplumsal ve bireysel ikiyüzlülük ve inkâr üzerine bir filmdir. Film burjuva bir ailenin tehdit altında olması so- runuyla başlar, ancak film ilerledikçe asıl sorunun Georges'da ve yaşadığı toplumda olduğu anlaşılır. Kırk yıl önce yaşanmış ve görmezden gelinmiş bir yalan ve üzeri örtülmüş bir katliamın asıl mağduru Majid'tir. Filmin başında mağdur olarak gördüğümüz Georges'un filmin sonunda suçluya dönüştüğünü görürüz. Aile yaşamını, işini, kariyerini, kısaca toplumsal statüsünü kaybetme korkusuyla Georges'un neler yapabileceğine şahit oluruz. Haneke Saklı filminin suçluluk duygusuyla ilgili olduğunu söyler:

“Dolayısıyla Saklı, insanın hayatta kalma aracı olarak başvurduğu yalana dair bir film... Gerçek hayatta da çok sık olduğu gibi. Her birimiz, yaptığımız itiraf edilmesi güç bazı şeyleri içimizde gizliyoruz ve bunları mümkün olduğunca çabuk unutmaya çabalıyoruz 'Saklı' filminde, Georges'un kişisel yalanı ile Fransız toplumunun kollektif yalanı paralellik gösterir. Film Haneke'nin kollektif kötülük olarak yorumladığı modern toplumun özeti gibidir. Ailesini ve olanaklarını paylaşmaktan tedirgin olan bir çocuğun, büyüdükten sonra olayları farklı yorumlaması gerekirken, Majid'i tehdit etmesi, aslında bugüne ait bir sorundur. Bu film aynı zamanda, suçluluk ve ihanet duygusu ile yıllarca en karanlık yerlerde beslenen intikam üzerinedir" (Cieutat ve Rouyer, 2014: 322).

Haneke filmlerinde, yaşanan katliamlara karşı modern toplumdaki bireylerin kayıtsız kalışı ile ilgilidir. Filmlerinde toplumları işledikleri suçlar üzerinden eleştirmek yerine, inkar etmeleri ve sessiz kalmaları üzerinden eleştirir ve seyirciyi bu konu üzerinde düşündürmeye çalışır. İşlenen suç kolektiftir ve bunun sonuçları da toplumları etkileyecektir.

“Richard Porton’la Saklı film üzerine yaptığı söyleşide bu meselenin sadece bir Fransa meselesi olmadığını hatırlatan Haneke'ye göre film, birkaç dokunuşla, Amerika'nın ya da Avusturya'nın işlemiş oldukları suçlarla kurdukları inkâr ve sessizlik ilişkisine dair kılınabilir -ne de olsa her devletin, her milletin kolektif bir suçu, karanlık köşeleri, kara lekeleri vardır- Ancak, Haneke'nin derdi işlenen kolektif suçun hakikatini göstermek, bu hakikati temsil etmek değil, suçun inkârı, inkârın tekerrürü üzerine düşünmektir. Bu evrensel, herkesin kapıldığı, inkârı mümkün kılan çekirdek duyguyla ilgilenir Haneke”. (Arslan, Türkmen; 2005)

Bu nedenle seyirciyi zorlayan, görmek ve çoğu kez duymak istemediği gerçeklerle yüzleştirerek, bir şeyler yapması gerektiğini hatırlatır. 


\section{SONUÇ YERINNE}

Modern toplumlarda ailenin tekinsizleşmesinin nedenini burjuvazinin bireylere dayattığı statükolar olduğunun altını çizen Haneke, filmlerinde modern bireylerin statülerini korumak için şiddeti, ırkçılığı, cinayetleri görmezden geldiklerini ve çok kolay yalan söyleyebildiklerini göstermektedir.

Toplumların giderek tekinsiz hale gelmesinin nedenini ailede başlayıp buradan topluma yayılan, görmezden gelme ve inkarın olduğunu savunur. Buradaki en sakıncalı unsur ise medya ve televizyondur. Her şeyin normalleşip doğal sayıldığı bir evrende, sorgusuz sualsiz gönüllü kul olmayı kabul etmiş bireylerin, tüketim toplumlarında özne olarak elde ettiği statükolarını kaybetmeme adına her şeyi yapabileceklerine tanık oluruz. Haneke bu durumu kollektif kötülük olarak yorumlamaktadır. Bu nedenle Haneke'nin filmlerindeki aileler, konumları tehlikeye girdiği andan itibaren tekinsiz bireylere dönüşürler. Bildiğimizi, tanıdığımızı sandığımız kişiler değillerdir artık. Çünkü toplumun mikro simgesi olan aile bireyleri, kendilerini tehdit eden durumundan kurtulmak için önce şiddetin mağduru olurlar, sonra da bizatihi nesnesi haline dönüşürler. Haneke filmlerinde modern birey karar verirken vicdanı ile değil, koşullarını elde ettiklerini kaybetmek istemediği için içgüdüsel olarak davranır, bu nedenle suça meyillidir. Statükosunu kaybetmemek için görmek istemediği şeylerin üstünü örterken daha büyük suçlar işler. Bu nedenle modern toplumlarda ailelerin karanlık tarafa geçme potansiyeli daha yüksektir. Ailelerin kaybedecekleri, bedelini ödeyecekleri şeyler büyüdükçe, daha da tekinsizleşeceklerdir. Haneke bu durumu şöyle özetler:

“Halının altına süpürdüğünüz şey, gün gelir halıyı harekete geçirir. Hepimiz suçluluk duygusuyla yaşıyoruz... İnsan her zaman isteyerek veya istemeyerek birileri tarafından suçlu bulunur. Acının olduğu her yerde suç da vardır. Suçsuz yaşayamayız. Bir toplumun ve bir sistemin parçası olarak kaçınılmaz olarak suçluyuz. Mesele, bununla nasıl başa çıktığımız” (Assheuer, 2013: 57).

Modern ailenin tekinsiz hallerini Benny'nin Videosu, 7.Kıta ve Saklı filmleri üzerinden açıklamaya çalışan bu makalede, filmler arasında ortak referanslar da saptanmıştır. Adı geçen filmlerin hepsinin gerçek olaylardan referans aldığı görülmektedir. Her filminde şiddet ister bireysel, ister toplumsal olsun en önemli belirleyicidir. Şiddet çoğu kez ailenin kendisinden kaynaklanmakta ve en korunaklı olan aile ve ev ortamını te- kinsizleşmektedir. Üç filmde de burjuva aile ortamı soğuk, donuk ve duygusuz ilişkilerden oluşur. Tüketim toplumunun nesnelerine hapsolmuş bireyleri, kendilerini çevreleyen nesnelere karşıda duyarsızlaşmıştır. Filmlerdeki aile bireylerinin oturma odalarında televizyondan dünyanın her yanında olan, terör, cinayet, katliam, intihar ve şiddet haberleriyle çevrilmiş dünyalarında kaçacakları nefes alacakları yer kalmamıştır. Haneke uzun yıllar televizyonda çalıştığı ve televizyonun insanları nasıl manipüle ettiğini iyi bildiği için, TV'nin olumsuzluklarını, her filminde eleştirmekten asla çekinmez. Televizyon aracılığıyla sıradanlaşmış şiddeti sürekli görmezden gelmenin, birey ya da toplum olarak bir şey yapmamanın cezasını yine bireyler çeker.

Modern toplumların bireyleri olduğu kadar seyircisi de olan bizleri de eleştirinin orta yerine yerleştirir. Bu kez seyirci olarak bizi kaçmak, görmezden gelmek gibi bir şansımız olmaksızın olayların ortasına koyar. Ve günlük hayatta görmek istemediğimiz her türlü olay ve durumla bizleri yüzleştirir. Filmleriyle kaçmaya çalıştığımız suçluluk duygusu ile karşı karşıya kalırız. Bu filmlerdeki ailelerin başına gelenler bizim başımıza gelse ne yaparız? Sorusuna cevap ararken buluruz kendimizi. Böylece suça ortak edip, farklı düşünme biçimlerine girmemizi sağlar. Bu nedenle Haneke filmleri seyirciye rahatlama ve kaçış sunmaz ve rahatsız etmeyi merkeze koyar. Seyirciye modern toplumlardaki tekinsiz ailelerden biri olup olmadığını hatırlattığı için, onun filmleri zorlayıcıdır ve kışkırtıcı olmak zorundadır.

\section{Notlar}

1- Türk Dil Kurumuna göre tekinsiz; "1. Tekin olmayan, uğursuz. 2. Güvenilir olmayan, muammalı (kişi, yer). 3. Belli davranış veya sözlerin bir toplumca, bir toplumsal grupça tehlikeli sayılması ve olumsuz yaptırımlara bağlanarak yasaklanması, tabu".

\section{Kaynakça}

Arslan, U. T., Saklı: Kolektif Suç, Bireysel Sorumluluk, http://www.agos.com.tr/tr/yazi/7986/sakli-kolektif-suc-bir eysel-sorumluluk (erişim tarihi: 12.07.2017)

Assheuer, T. (2013). Yakın Plan Haneke (Çev: N. Pakkan), İstanbul: Agora Kitaplığı.

Baudrillard, J. (2008). Tüketim Toplumu (çev. H. Deliceçaylı, F. Keskin), İstanbul: Ayrıntı Yayınları. 
Bedir, U. (2014). "Haneke Sinemasında Hazın Engellenmesi”, içinde Cheviron (ed.) Haneke Huzursuz Seyirler Diler (çev. T. Nilgün), İstanbul: Eks Libris Sinema.

Brown, B. (1989). Marks, Freud ve Günlük Hayatın Eleştirisi (çev: Y. Alogan), İstanbul: Ayrıntı Yay.

Cieutat M. § Rouyer P. (2014). Haneke Haneke'yi Anlatiyor (Çev: S. İdemen), İstanbul: Everst Yay.

Cheviron, N. (2014). Haneke Huzursuz Seyirler Diler, İstanbul: Ekslibris Yayıncılık

Derrida, J. (2001). Marx’ın Hayaletleri (Çev: Alp Tümertekin), İstanbul: Ayrıntı Yayınları

Engels, F. (2003). Ailenin, Özel Mülkiyetin ve Devletin Kökeni, İstanbul: Eriş Yay.

Eroğlu, F. (2014). Gündelik Faşizmler: Modern Burjuva Toplumunda Kötülük ve Gündelik Yaşamda Kötülüğün yeniden Üretimi, Yayınlanmamış Yüksek Lisans Tezi, Doç. Dr. F Keskin, İstanbul Bilgi üniversitesi, Sosyal Bilimler Enstitüsü, Felsefe ve Toplumsal Düşünce Yüksek Lisans Programı, İstanbul.

Featherstone, M. (1996). Postmodernizm ve Tüketim Kültürü (Çev: M. Küçük), İstanbul: Ayrıntı Yayınları.

Foucault, M. (2014). Özne ve İktidar (Çev. I. Ergüden ve O. Akınhay), İstanbul: Ayrıntı Yayınları.

Freud, S. (2016). Sanat ve Edebiyat (çev: E. Kapkın ve A. Teşken), İstanbul: Payel Yay.

Güçbilmez, B. (2003). Tekinsiz Tiyatro: Sahibinin Sesi/Sevim Burak'in Metninde Tekinsiz Teatrallik ve Minör Ses'in Temsili, http:// dergiler.ankara.edu.tr/dergiler/13/181/1426 (erişim tarihi: 15.07.2017)

Güçbilmez, B. (2005). Tekinsiz teatrallik/ Sahne-dışı'nın Temsili: Eurydike Olarak Beckett Oyunları, http://dergiler.ankara.edu. tr/dergiler/13/192/1506 (erişim tarihi: 30.08.2017)

http://www.tdk.gov.tr (erişim tarihi: 15.05.2017)

Kılınç, B. (2014). M. Haneke Filmleri: Modern Uygarlığın Hayal Kırıklığı, Konya: Literatürk Academia Yayınlan.

Kırmızı, H. (2017). Sinema ve Tv'nin Nesneler Sistemi Düşüncesi Üzerinden Tekrar Yorumlanması, Yayınlanmamış Yüksek Lisans Tezi, Prof. Dr. 0. Adanır, Dokuz Eylül Üniversitesi Güzel Sanatlar Enstitüsü, Film Tasarımı Ana Sanat Dalı, İzmir

Laustsen, C. § Diken, B. (2010). Filmlerle Sosyoloji (Çev: Sona Ertekin), İstanbul: Metis Yayınları.
Marx ve Engels (2009). Komünist Manifesto (Çev: C. Üster ve N. Deriş), İstanbul: Can Yay.

Rodley, C. (2013). David Lynch Tekinsizin Sineması (Çev: S. Özgül), İstanbul: Agora Kitaplığı.

\section{Görsel Kaynaklar}

Fotoğraf 1. Benny’nin Videosu (1992)

Fotoğraf 1. 7. Kıta Filmi (1989)

Fotoğraf 3. Saklı Filmi (2005) 